\title{
Perspektywy dla informacji $w$ administracji. Kierunki zmian $w$ dostępie i ponownym wykorzystywaniu informacji publicznej ${ }^{2}$
}

\author{
Wpłyną: 3.11.2020. Akceptacja: 11.07.2021
}

\section{Streszczenie}

Celem przeprowadzonych badań jest przedstawienie kierunków zmian polskiego prawa dostępu i ponownego wykorzystywania informacji publicznej, ukazujących perspektywy dla informacji w administracji. Służy temu diagnoza najistotniejszych problemów $\mathrm{w}$ wykonywaniu gwarantowanych przepisami prawa uprawnień informacyjnych, analiza dorobku judykatury oraz postulatów nauki prawa. Wyniki badań wskazują, że poruszane problemy i wątpliwości dotyczą fundamentalnych aspektów jawności życia publicznego. Aktualne kierunki zmian wpisują się w budowę administracji opartej na otwartych danych, która nie tylko zapewni szeroki dostęp do informacji publicznej, ale również wytworzy i zgromadzi dane gotowe do ich dalszego gospodarczego wykorzystywania przez sektor prywatny. Wdrożenie tych zmian będzie znacznym wyzwaniem dla administracji publicznej. Przeprowadzone badania umożliwiły sfomułowanie postulatów i uwag natury legislacyjnej kierowanych do ustawodawcy, a także rozwiązań praktycznych dotyczących organizacji aparatu administracji.

Słowa kluczowe: informacja, informacja publiczna, dostęp do informacji publicznej, ponowne wykorzystywanie, otwarte dane, informacja w administracji, jawność działań administracji.

1 Dr Łukasz Nosarzewski - Uczelnia Łazarskiego w Warszawie (Polska); e-mail: 1.nosarzewski@wp.pl; ORCID: 0000-0001-8769-6757.

2 Badania wykorzystane w artykule nie zostały sfinansowane przez żadną instytucję. 


\title{
ŁUKASZ NOSARZEWSKI
}

\section{Perspectives for Information in Administration: Directions of Changes in Accessing and Reusing Public Information ${ }^{3}$}

\begin{abstract}
The purpose of the research conducted is to present the directions of changes in the Polish legislation on accessing and reusing public information, showing perspectives for public information in administration. The pursue of it is accompanied by a diagnosis of the most important issues in the execution of the guaranteed information powers, and also by an analysis of the judicature's work and postulates of the doctrine in this regard. The object of the study using the method of dogmatic-legal analysis covers Polish and European normative acts, scientific publications, the case law of administrative courts and the Constitutional Tribunal. The results indicate that the issues and doubts raised concern the fundamental aspects of access to public information, as well as detailed issues related to establishing a legal framework for the principles of reusing that information. The current directions of changes fit into building administration that is based on open public data, which will not only ensure wide access to public information but will also create and gather data in a way that will allow for the further economic use of those data by the private sector. Resolving the existing problems in exercising information rights and implementing the projected changes will both pose a considerable challenge to the public administration. The conducted research allowed for formulating legislative postulates and remarks addressed to the legislator, as well as practical solutions concerning the organisation of the administration apparatus.
\end{abstract}

Keywords: information, public information, access to public information, reuse, open data, information in administration.

3 The research in this article has not been supported financially by any institution. 
$\mathrm{N}$ a współczesne funkcjonowanie administracji publicznej istotny wpływ mają dynamiczne zmiany związane z postępem technologicznym i komunikacyjnym umożliwiające pozyskiwanie i przetwarzanie coraz większej ilości informacji. W języku potoczonym „informacja” oznacza to, co powiedziano lub napisano o kimś lub o czymś, powiadomienie o czymś, zakomunikowanie czegoś, wiadomość, wskazówka, pouczenie ${ }^{4}$. W prawie administracyjnym można wyróżnić „informację w administracji publicznej", będącą wiedzą odnoszącą się do podmiotów, przedmiotów, działań, faktów czy stanów, która stanowi istotny czynnik umożliwiający działania organów administracji publicznej lub efekt tych działań ${ }^{5}$. Postępująca informatyzacja państw sprzyja sprawnemu załatwianiu spraw obywateli, ale i skutkuje gromadzeniem szerokiego zasobu informacji na ich temat z różnych obszarów działania administracji publicznej. Towarzyszy temu rozwój społeczeństwa opartego na informacji, aktywnie uczestniczącego w życiu publicznym z wykorzystaniem nowych technologii. Dla zaangażowania w sprawy państwa niezbędna jest jawność działań administracji publicznej, rozumiana jako stan, w którym te działania są względnie przejrzyste dla wszystkich podmiotów zainteresowanych lub posiadających w przejrzystości działań administracji konkretny interes prawny. Przejawia się ona w istnieniu i sprawnym funkcjonowaniu mechanizmów umożliwiających zapoznanie się z informacją dotyczącą działań administracji publicznej ${ }^{6}$. Podstawowym takim mechanizmem jest polityczne prawo dostępu do informacji publicznej, które stwarza obywatelom realne możliwości kontroli państwa. Jego dopełnieniem jest prawo do ponownego wykorzystywania informacji publicznej, będące prawem o charakterze gospodarczym i użytkowym, zmierzającym do pełnego spożytkowania przez społeczeństwo potencjału danych publicznych. Informacja publiczna to bowiem nie tylko źródło wiedzy, ale też wartościowy surowiec potrzebny do wytworzenia nowych dóbr, produktów i usług. O ile zatem dostęp do informacji publicznej gwarantuje prawo do wiedzy o działaniach państwa, a jego celem jest kontrola i przejrzystość władzy publicznej, to gospodarcze prawo do ponownego wykorzystywania obejmuje komercyjne lub niekomercyjne używanie informacji ze sfery publicznej i czerpanie z tego korzyści przez podmioty prywatne. Pomimo różnic,

$4 \quad$ Dubisz S. (red.), Wielki Stownik Języka Polskiego PWN, t. 2, H-N, Warszawa 2018, s. 113.

5 P. Fajgielski, Informacja $w$ administracji publicznej. Prawne aspekty gromadzenia, udostępniania $i$ ochrony, Wrocław 2007, s. 15.

6 M.I. Ulasiewicz, Administracyjnoprawne aspekty jawności działań administracji publicznej, Łódź 2017, s. 21. 
dostęp do informacji i ponowne wykorzystywanie pozostają względem siebie w ścisłej relacji, stanowiąc połączone źródło uprawnień informacyjnych obywateli w polskim porządku prawnym urzeczywistniających stan jawności działań administracji publicznej. Zasady korzystania z tych uprawnień, w szczególności dostępność i użyteczność informacji publicznej dla społeczeństwa, wyznaczają jej perspektywy, których przedstawienie jest celem podjętych badań. Dla jego realizacji zostaną poddane krytycznej analizie zarówno obowiązujące przepisy prawa regulujące dostęp do informacji publicznej oraz jej ponowne wykorzystywanie, jak i projektowane zmiany, które polski ustawodawca zamierzał lub zamierza wprowadzić. Tłem dla tej analizy będzie dorobek judykatury oraz postulaty doktryny prawa, które od lat ukazują najistotniejsze problemy polskiego prawa informacyjnego.

Dostęp do informacji publicznej został uregulowany przepisami ustawy z dnia 6 września 2001 r. o dostępie do informacji publicznej (dalej „u.d.i.p.”) ${ }^{7}$, które konkretyzują konstytucyjne prawo do uzyskiwania informacji o działalności organów władzy publicznej oraz osób pełniących funkcje publiczne, zagwarantowane w art. 61 ust. 1 Konstytucji RP. Stosowanie tej ustawy od początku jej obowiązywania wywoływało wiele sporów i wątpliwości. Od 2001 r. była ona wielokrotnie modyfikowana, chociaż tylko dwukrotnie dokonano bezpośrednich zmian o istotnym znaczeniu wprowadzających instytucje Centralnego Repozytorium Informacji Publicznej (dalej "CRIP") oraz ponownego wykorzystywania informacji publicznej ${ }^{8}$ czy też Scentralizowanego Systemu Dostępu do Informacji Publicznej ${ }^{9}$. Kolejne zmiany nie usuwały narastających od lat problemów wykładni i stosowania przepisów u.d.i.p., a ich rozwiązywanie stało się zadaniem sądów. Ostatnią próbą wprowadzenia nowej kompleksowej regulacji był projekt ustawy o jawności życia publicznego (dalej też „projekt u.j.ż.p.") przedstawiony w dniu 25 października 2017 r. przez członka Rady Ministrów Koordynatora Służb Specjalnych ${ }^{10}$. Projekt miał na celu ujęcie w jednym akcie prawnym zasad jawności życia publicznego oraz składania oświadczeń majątkowych, dlatego też planowana ustawa miała zastąpić dotychczasowe przepisy ustawy z dnia 21 sierpnia 1997 r. o ograniczeniu prowadzenia działalności gospodarczej przez osoby pełniące funkcje publiczne, ustawy z dnia 6 września $2001 \mathrm{r}$. o dostępie do informacji publicznej oraz ustawy z dnia 7 lipca 2005 r. o działalności

\section{Dz.U. z 2019 r., poz. 1429.}

8 Ustawa z dnia 16 września 2011 r. o zmianie ustawy o dostępie do informacji publicznej oraz niektórych innych ustaw, Dz.U. z 2011 r. Nr 204, poz. 1195.

9 Ustawa z dnia 8 listopada 2013 r. o zmianie ustawy o dostępie do informacji publicznej, Dz.U. 2013, poz. 1474 .

10 Projekt ustawy udostępniono na stronie Biuletynu Informacji Publicznej Rządowego Centrum Legislacji pod adresem: https://legislacja.rcl.gov.pl/projekt/12304351/katalog/12465433\#12465433 (dostęp: 30.10.2020). 
lobbingowej w procesie stanowienia prawa. Propozycja nowej ustawy wywołała ożywioną debatę. W toku przeprowadzonych konsultacji publicznych i opiniowania zgłoszono do projektu liczne uwagi. W ich efekcie projektowane przepisy uległy znacznym zmianom, a finalna wersja projektu, będąca przedmiotem badań, datowana jest na dzień 8 stycznia 2018 r. Ostatecznie prace nad projektem u.j.ż.p. zostały zatrzymane na etapie jego rozpatrzenia przez Stały Komitet Rady Ministrów, co nie wpływa na ich wartość jako materiału poglądowego ukazującego możliwy kierunek zmian w przyszłości.

Podstawowym problemem na gruncie dostępu do informacji publicznej jest określenie znaczenia pojęcia „informacji publicznej”, zgodnie z ustawą będącej każdą informacją o sprawach publicznych. Takiej definicji tłumaczącej nieznane pojęcie innym określeniem nieznanym zasadnie zarzuca się niejasność i błąd logiczny ${ }^{11}$. Jedynym jej uzupełnieniem jest otwarty katalog spraw wskazanych w art. 6 ust. 1 u.d.i.p., należących do kategorii informacji publicznych o polityce wewnętrznej i zagranicznej, o władzach publicznych oraz innych podmiotach wykonujących zadania publiczne i zasadach ich funkcjonowania, danych publicznych i majątku publicznym. Ustawowa definicja informacji publicznej ma charakter przedmiotowy, bazujący na pojęciu „sprawy publicznej”, przy czym nie pokrywa się z konstytucyjnym określeniem prawa do informacji. W art. 61 ust. 1 Konstytucji RP posłużono się kryterium mieszanym, podmiotowo-przedmiotowym, stanowiąc, że prawo do informacji dotyczy działalności (element przedmiotowy) wymienionych w tym przepisie podmiotów (element podmiotowy) ${ }^{12}$, a zatem organów władzy publicznej, osób pełniących funkcje publiczne, organów samorządu gospodarczego i zawodowego, a także innych osób oraz jednostek organizacyjnych w zakresie, w jakim wykonują one zadania władzy publicznej i gospodarują mieniem komunalnym lub majątkiem Skarbu Państwa. Z tych względów wyodrębnić można trzy sposoby definiowania pojęcia informacji publicznej. Pierwsza definicja oparta jest na Konstytucji RP i obejmuje każdy rodzaj działania podmiotów zobowiązanych do udzielania informacji publicznej, niezależnie od tego, czy dotyczy on sprawy publicznej. Drugie ujęcie przedmiotowe wywodzone jest $\mathrm{z}$ treści art. 1 ust. 1 u.d.i.p. i odwołuje się do pojęcia "ssprawy publicznej”. Trzecie ujęcie mieszane podmiotowo-przedmiotowe zakłada dwuetapowe badanie publicznego waloru informacji poprzez ustalenie, czy wniosek o udostępnienie informacji publicznej został skierowany do podmiotu zdefiniowanego w art. 61 Konstytucji RP, a następnie, czy żądana infor-

11 P. Szustakiewicz, Problemy dostępu do informacji publicznej na tle orzecznictwa sądów administracyjnych, „Samorząd Terytorialny” 2015, 4, s. 59.

12 W. Sokolewicz. K. Wojtyczek, [w:] L. Garlicki, M. Zubik (red.), Konstytucja Rzeczypospolitej Polskiej. Komentarz, t. 2, Warszawa 2016, s. 474. 
macja dotyczy sprawy o charakterze publicznym zgodnie z art. 1 ust. 1 u.d.i.p. ${ }^{13}$. Taka rozbieżność możliwych interpretacji skłoniła przedstawicieli doktryny do poszukiwania nowej ustawowej definicji. Proponowano wprowadzenie określenia odwołującego się do kryteriów merytorycznych wykonywania zadania publicznego oraz gospodarowania mieniem publicznym, uzupełnionych kryterium technicznym, w myśl którego żądana informacja musi być utrwalona i znajdować się w posiadaniu podmiotu obowiązanego do jej udostępnienia ${ }^{14}$. Takie ujęcie poddano jednak zasadnej krytyce, wskazując dalsze niejasności uniemożliwiające ustalenie granicy pomiędzy informacją publiczną a informacją pozbawioną tego charakteru, co w szczególności dotyczy dokumentów wewnętrznych ${ }^{15}$. Pojęcie "dokumentów wewnętrznych" zostało ukształtowane przez orzecznictwo sądów administracyjnych i doktrynę prawa na gruncie przedmiotowej definicji informacji publicznej. Uznano, że służą one wprawdzie realizacji jakiegoś zadania publicznego, ale nie przesądzają o kierunkach działania organu. Mają na celu wymianę informacji, zgromadzenie niezbędnych materiałów, uzgadnianie poglądów i stanowisk. Mogą mieć przy tym dowolną formę, nie są wiążące co do sposobu załatwienia sprawy, nie są w związku z tym wyrazem stanowiska organu, nie stanowią więc informacji publicznej ${ }^{16}$.

Dokumenty wewnętrzne mogą też być fragmentem przygotowań do powstania aktu będącego formą działalności danego podmiotu ${ }^{17}$. Sądy uznały, że charakter taki posiada korespondencja elektroniczna, w tym także mailowa osoby wykonującej zadania publiczne z jej współpracownikami, nawet jeżeli w jakiejś części dotyczy wykonywanych przez tę osobę zadań publicznych, wewnętrzna korespondencja urzędowa o charakterze roboczym, odnosząca się jedynie do spraw organizacyjnych i porządkowych i nie umieszczona w aktach sprawy, informacje techniczne, dotyczące np. sposobu funkcjonowania danego narzędzia użytkowanego przez organ, opinie ekspertów, jeżeli nie dotyczą konkretnego aktu będącego już przedmiotem toczącego się procesu legislacyjnego, wykazy wejść i wyjść do ministerstwa lub terminarz spotkań, kalendarz, czy inne dokumenty związane

13 P. Szustakiewicz, Definicja informacji publicznej w orzecznictwie Naczelnego Sądu Administracyjnego „,Przegląd Prawa Publicznego" 2016, 10, s. 53-55.

14 A. Młynarska-Sobaczewska, P. Fajgielski, A. Piskorz-Ryń, G. Sibiga, Ekspertyza prawna "Rozwiazania mogące stanowić podstawę do zmian przepisów regulujących zasady dostępu do informacji publicznej i jej ponownego wykorzystywania", https://mc.bip.gov.pl/fobjects/download/96100/rozwiazania-mogace-stanowicpodstawe-do-zmian-przepisow-regulujacych-zasady-pdf.html, s. 7-8 (dostęp: 30.10.2020).

15 P. Szustakiewicz, Przyszłość regulacji o dostępie do informacji publicznej (uwagi na tle ekspertyzy prawnej „Rozwiązania mogace stanowić podstawę do zmian przepisów regulujących zasady dostępu do informacji publicznej i jej ponownego wykorzystywania" sporządzonej przez Instytut Nauk Prawnych PAN), [w:] J. Sługocki (red.), Dziesięć lat polskich doświadczeń w Unii Europejskiej. Problemy prawnoadministracyjne, t. 2, Wrocław 2014, s. 730.

16 Wyrok NSA z 20.09.2016 r., I OSK 2649/15, CBOSA.

17 Wyrok NSA z 7.10.2015 r., I OSK 1883/14, CBOSA. 
z planowaniem działalności organu ${ }^{18}$. Wszystkie powyższe dokumenty zostały więc wytworzone $w$ ramach wykonywania zadania publicznego lub gospodarowania mieniem publicznym i jako utrwalone na nośniku znajdują się w posiadaniu organu, a pomimo tego orzecznictwo wyłączyło je z zakresu przedmiotowego dostępu do informacji publicznej. Inne ujęcie pojęcia informacji publicznej znalazło się w art. 2 ust. 1 pkt 2 projektu u.j.ż.p. definiującym ją jako informację o działalności organów władzy publicznej oraz osób pełniących funkcje publiczne, działalności organów samorządu gospodarczego i zawodowego, a także innych osób oraz jednostek organizacyjnych w zakresie, w jakim wykonują one zadania władzy publicznej i gospodarują mieniem komunalnym lub majątkiem Skarbu Państwa. Definicja ta stanowiła powtórzenie art. 61 ust. 1 Konstytucji RP, co należy ocenić negatywnie. Przede wszystkim w ustawach nie należy powielać przepisów Konstytucji RP, co wynika z jej art. 8 ust. 2. Istota bezpośredniego stosowania określonych norm prawnych sformułowanych $w$ konstytucji polega na tym, że nie należy ich rozwijać w aktach niższego rzędu ${ }^{19}$. Dlatego też, zakładając dostateczną określoność pojęcia informacji publicznej na gruncie art. 61 ust. 1 Konstytucji RP, ustawa nie powinna wprowadzać odrębnego definiowania. Tymczasem ustawodawca konsekwentnie zmierza do ustawowego dookreślenia zakresu pojęcia informacji publicznej, co przy wszystkich dotychczasowych wątpliwościach interpretacyjnych jest kierunkiem prawidłowym. Podzielić należy konstatację, że nowa definicja musi być nad wyraz ogólna, aby swoim zakresem objąć jak największą liczbę danych zasługujących na upublicznienie. Pewnym rozwiązaniem mogłoby być skonkretyzowanie katalogu dotyczącego spraw publicznych, ujętego $w$ art. 6 u.d.i.p., przy zachowaniu jego otwartości ${ }^{20}$. Wydaje się, że taką ogólność zapewniałaby definicja pojęcia informacji sektora publicznego, już obecna na gruncie ustawy z dnia 25 lutego 2016 r. o ponownym wykorzystywaniu informacji sektora publicznego. Informacja publiczna mogłaby dotyczyć każdej utrwalonej informacji lub jej części, posiadanej przez podmioty zobowiązane, przy równoczesnym określeniu szczegółowego katalogu wyłączeń precyzyjnie wskazującego, co informacją publiczną nie jest. Taki katalog powinien uwzględniać bogaty dorobek judykatury, zwłaszcza w odniesieniu do kategorii „dokumentu wewnętrznego”. Równocześnie zasadne byłoby doprecyzowanie katalogu ogólnie ujętego w art. 6 u.d.i.p., m.in. o ekspertyzy i opinie finansowane ze środków publicznych, co zaproponowano już w art. 7 ust. 1 pkt 4 lit. f projektu u.j.ż.p. Interesujący kierunek zmian wskazano też w art. 9 pro-

18 Wyrok NSA z 12.04.2019 r., I OSK 1648/17 oraz z 2.12.2015 r., I OSK 2337/15, CBOSA.

19 Wyrok TK z 9.11.1999 r., K 28/98, OTK 1999/7/156.

20 K. Tomaszewska, Dostęp do informacji publicznej w świetle obowiązujących i przyszłych regulacji, Warszawa 2019, s. 192. 
jektu u.j.ż.p., przy czym obowiązek stworzenia, prowadzenia, aktualizacji i udostępniania w Biuletynie Informacji Publicznej rejestru umów cywilnoprawnych powinien dotyczyć wszystkich tych umów bez ograniczenia kwotowego, lecz z uwzględnieniem ograniczeń już uregulowanych $w$ art. 5 u.d.i.p. dotyczących m.in. ochrony informacji niejawnych, prywatności i tajemnicy przedsiębiorstwa.

Kolejnym zasadniczym problemem na gruncie przepisów u.d.i.p. jest szczególny przypadek udostępniania tzw. informacji przetworzonej. Zgodnie z art. 3 ust. 1 u.d.i.p. prawo do informacji publicznej obejmuje uprawnienia uzyskania informacji przetworzonej w takim zakresie, w jakim jest to szczególnie istotne dla interesu publicznego. Po dokonaniu analizy orzecznictwa w zakresie tej przesłanki wskazać należy, że sądy administracyjne przewidują trzy zasadnicze wymogi dla jej wykazania, które muszą być spełnione łącznie. Po pierwsze istotna jest intencja wnioskodawcy i wskazany przez niego cel przetworzenia. Po drugie ważna jest istota i charakter żądanej informacji, gdyż uzyskanie danej informacji przetworzonej powinno mieć realne znaczenie dla funkcjonowania określonych struktur publicznych w konkretnej dziedzinie życia społecznego i wpływać na usprawnienie wykonywania zadań publicznych dla dobra wspólnego danej społeczności. Po trzecie zaś istotne znaczenia ma charakter lub pozycja podmiotu żądającego udzielenia informacji publicznej, a zwłaszcza realne możliwości wykorzystania uzyskanych przez niego danych ${ }^{21}$. Dlatego też osoba żądająca informacji publicznej przetworzonej powinna dla jej uzyskania wykazać nie tylko, że ta informacja jest ważna dla dużego kręgu potencjalnych odbiorców, lecz także, że jej uzyskanie stwarza realną możliwość wykorzystania danych dla poprawy funkcjonowania np. organu administracji publicznej, a przez to poprawy ochrony interesu publicznego ${ }^{22}$. Przyjmuje się zatem, że charakter informacji przetworzonej mogą mieć informacje, które należy wytworzyć na zamówienie wnioskodawcy, wymagające specjalnych analiz, obliczeń, zestawień statystycznych, połączonych z zaangażowaniem określonych środków osobowych i finansowych organu, innych niż te wykorzystywane w bieżącej działalności ${ }^{23}$. Równocześnie sądy wskazują, że selekcja dokumentów i ich analiza pod względem treści są zwykłymi czynnościami, które nie dają podstaw do zakwalifikowania żądania jako dotyczącego informacji przetworzonej ${ }^{24}$, jak również za takie nie mogą zostać uznane informacje przechowywane w zbiorach informatycznych, które są możliwe do uzyskania w ramach funkcjonalności stosownych systemów oprogramowania, ze stanowiska o najwyższych uprawnieniach

21 Wyrok NSA z 23.11.2018 r., I OSK 2951/16, CBOSA.

22 Wyrok NSA z 5.03.2013 r., I OSK 3097/12, CBOSA.

23 Wyrok NSA z 23.01.2019 r., I OSK 431/17, CBOSA.

24 Wyrok WSA w Opolu z 22.08.2018 r., II SA/Op 334/18, CBOSA. 
dostępu ${ }^{25}$. Przegląd orzecznictwa bezsprzecznie obrazuje więc skalę problemu będącego skutkiem braku ustawowych kryteriów uznania informacji za przetworzoną oraz spełnienia przesłanki szczególnej istotności dla interesu publicznego. Próbą zmiany takiego stanu rzeczy była propozycja wprowadzenia w art. 2 ust. 1 pkt 4 projektu u.j.ż.p. odrębnej definicji legalnej informacji publicznej przetworzonej, rozumianej jako każda informacja publiczna, której podmiot zobowiązany do udostępnienia nie posiada w chwili wpłynięcia wniosku o udostępnienie informacji publicznej, ale wytwarza ją dla wnioskodawcy na podstawie posiadanych zasobów informacyjnych, a do jej wytworzenia wymagane są dodatkowe nakłady. Z przetworzenia informacji wyłączono czynności skanowania, anonimizacji lub prostego zestawienia informacji. Taka definicja tylko częściowo realizowała postulaty doktryny i orzecznictwa. Sądy wielokrotnie wskazywały, że za informację przetworzoną można uznać taką, której przygotowanie jest zdeterminowane szerokim zakresem (przedmiotowym, podmiotowym, czasowym) wniosku, wymagającym zgromadzenia i przekształcenia (zanonimizowania i usunięcia danych objętych tajemnicą prawnie chronioną) znacznej ilości dokumentów, gdyż w pewnych wypadkach szeroki zakres wniosku może wymagać takich działań organizacyjnych i angażowania środków osobowych, które zakłócają normalny tok działania podmiotu zobowiązanego i utrudniają wykonywanie przypisanych mu zadańn ${ }^{26}$. Dodatkowo w art. 5 ust. 3 projektu u.j.ż.p. zachowano dodatkową przesłankę uzyskania informacji publicznej przetworzonej, wymogu uzasadnienia istotnego interesu publicznego, chociaż zrezygnowano z elementu "szczególnej istotności”, co powinno nieco ułatwić jej wykazanie wnioskodawcom. Nadal jednak przesłance tej można zarzucić nieprecyzyjny charakter umożliwiający uznaniowość działań podmiotów zobowiązanych w odpowiedzi na żądanie przetworzenia informacji. Dlatego za aktualny i zasadny uznać trzeba postulat wprowadzenia definicji pojęcia „przetworzenia informacji publicznej", rozumianego jako operacja podmiotu zobowiązanego na posiadanych przez niego informacjach publicznych, która prowadzi do powstania informacji jakościowo nowej, przygotowanej w odpowiedzi na konkretny wniosek, a jej wytworzenie wiąże się ze znacznym nakładem pracy lub innym nakładem, w tym finansowym ${ }^{27}$. Podobnie należałoby doprecyzować szczególną przesłankę istotności dla interesu publicznego w przetworzeniu, wykorzystując dotychczasowy dorobek orzecznictwa, z próbą rekonstrukcji składających się na abstrakcyjną kategorię interesu publicznego wartości, opartą na art. 31 ust. 3 Konstytu-

\footnotetext{
25 Wyrok WSA w Warszawie z 9.07.2014 r., VIII SA/Wa 529/14, CBOSA.

26 Wyrok NSA z 21.10.2016 r., I OSK 446/15, CBOSA.

27 Zob. A. Młynarska-Sobaczewska, P. Fajgielski, A. Piskorz-Ryń, G. Sibiga, op. cit., s. 30-31.
} 
cji $\mathrm{RP}^{28}$. Postuluje się takie doprecyzowanie obecnego art. 3 ust. 1 pkt 1 u.d.i.p., aby prawo dostępu do informacji publicznej obejmowało uprawnienia do uzyskania informacji publicznej przetworzonej $\mathrm{w}$ takim zakresie, $\mathrm{w}$ jakim przetworzenie informacji publicznej jest usprawiedliwione realnym celem wykorzystania informacji przetworzonej i wpłynie na poprawę wykonywania zadań publicznych przez podmiot zobowiązany, albo jest istotne dla jednej z wartości: bezpieczeństwa lub porządku publicznego, ochrony środowiska, ochrony zdrowia publicznego, ochrony moralności publicznej lub wolności i prawa innych osób.

W świetle powyższych uwag należy wskazać, że problemy praktyczne w stosowaniu przepisów u.d.i.p. dotyczą fundamentalnych pojęć stanowiących o istocie systemu dostępu do informacji publicznej. Pomimo iż dotychczas zaproponowano kompleksową nową regulację prawną tej materii, wydaje się, że ważne zmiany można wprowadzić częściową nowelizacją, odnoszącą się tylko do niektórych aktualnie obowiązujących przepisów u.d.i.p. Inaczej jest w przypadku ponownego wykorzystywania informacji publicznej, obecnie unormowanego ustawą z dnia 25 lutego 2016 r. o ponownym wykorzystywaniu informacji sektora publicznego (dalej "u.p.w.i.s.p." ${ }^{29}$. Na etapie procesu legislacyjnego znajduje się projekt ustawy z dnia 21 sierpnia 2020 r. o otwartych danych i ponownym wykorzystywaniu informacji sektora publicznego (dalej „projekt u.o.d.p.w.”) ${ }^{30}$, który przewiduje utratę mocy dotychczasowej ustawy. Celem tej regulacji jest zwiększenie podaży otwartych danych i stworzenie optymalnego otoczenia regulacyjnego dla efektywnego wykorzystywania informacji sektora publicznego. Równocześnie potrzeba uchwalenia nowej ustawy wynika z konieczności implementacji dyrektywy Parlamentu Europejskiego i Rady (UE) 2019/1024 z dnia 20 czerwca 2019 r. w sprawie otwartych danych i ponownego wykorzystywania informacji sektora publicznego (dalej „dyrektywa 2019/1024/UE") ${ }^{31}$, która obowiązuje od dnia 16 lipca 2019 r. Została ona uchwalona, aby niwelować bariery ponownego wykorzystywania w skali europejskiej i dostosować ramy prawne do postępu technologii cyfrowych. Państwa członkowskie mają obowiązek jej implementacji do dnia 17 lipca 2021 r. i od tego dnia stracą moc dotychczasowe przepisy dyrektywy Parlamentu Europejskiego i Rady 2003/98/ WE z dnia 17 listopada $2003 \mathrm{r}$. w sprawie ponownego wykorzystywania informacji sektora publicznego (dalej „dyrektywa 2003/98/WE”) ${ }^{32}$ oraz dyrektywy Parlamentu Europejskiego i Rady 2013/37/UE z dnia 26 czerwca 2013 r. zmieniająca dyrektywę

\footnotetext{
28 Wyrok TK z 17.12.2003 r., SK 15/02, OTK-A 2003/9/103.

29 Dz.U. z 2019 r., poz. 1446.

30 Zob. https://legislacja.rcl.gov.pl/projekt/12337400/katalog/12711402\#12711402.

31 Dz. Urz. UE L 172 z 26.06.2019, s. 56-83.

32 Dz. Urz. UE L 345 z 31.12.2003, s. 90-96.
} 
2003/98/WE w sprawie ponownego wykorzystywania informacji sektora publicznego (dalej „dyrektywa 2013/37/UE”) ${ }^{33}$. Obie uchylane dyrektywy stanowiły przejaw pierwszej harmonizacji zasad i procedur ponownego wykorzystywania dokumentów publicznych w skali Unii Europejskiej i zostały implementowane do polskiego porządku prawnego $\mathrm{w}$ dotychczasowych przepisach. Aktualnie zatem na szczeblu europejskim kierunek zmian w ponownym wykorzystywaniu informacji publicznej wyznacza dyrektywa 2019/1024 wprowadzająca wiele istotnych modyfikacji.

Wszystkie dotychczasowe dyrektywy unijne konsekwentnie definiowały pojęcie "ponownego wykorzystywania” jako wykorzystywanie przez osoby fizyczne lub prawne dokumentów będących w posiadaniu organów sektora publicznego do celów komercyjnych lub niekomercyjnych innych niż ich pierwotne przeznaczenie $\mathrm{w}$ ramach zadań publicznych, dla których te dokumenty zostały wyprodukowane. Z zakresu tego pojęcia wyłączono wymianę dokumentów między organami sektora publicznego służącą wyłącznie wykonywaniu ich zadań publicznych. Zgodnie z art. 2 ust. 2 p.w.i.s.p. przez ponowne wykorzystywanie należy rozumieć wykorzystywanie przez osoby fizyczne, osoby prawne i jednostki organizacyjne nieposiadające osobowości prawnej, zwane dalej „użytkownikami”, informacji sektora publicznego w celach komercyjnych lub niekomercyjnych innych niż pierwotny publiczny cel, dla którego informacja została wytworzona. Polska implementacja unijnej definicji jest nieprecyzyjna i nie odnosi się do kategorii zadań publicznych. Takie zdefiniowanie „ponownego wykorzystywania” zostało utrzymane $\mathrm{w}$ art. 2 pkt 13 projektu u.o.d.p.w., a zatem aktualne pozostają postulaty funkcjonalnego dookreślenia tego pojęcia jako używanie przez każdego informacji sektora publicznego, będącej w posiadaniu podmiotów zobowiązanych, dla wytworzenia produktów, dóbr lub usług o wartości dodanej, w innym celu niż wykonywanie zadań publicznych, przy czym cel ten może być komercyjny lub niekomercyjny ${ }^{34}$. O ile dyrektywa 2003/98/WE nie przewidywała obowiązków zapewnienia dostępu do dokumentów i zezwalania na ich ponowne wykorzystywanie, to już dyrektywa 2013/37/UE takie obowiązki wprowadziła wobec organów sektora publicznego. Kolejna dyrektywa 2019/1024 rozszerzyła zakres podmiotowy ponownego wykorzystywania o przedsiębiorstwa publiczne, które zgodnie z jej art. 2 pkt 3 prowadzą m.in. działalność w sektorach gospodarki wodnej, energetyki, transportu, usług pocztowych bądź działają w charakterze podmiotów świadczących usługi publiczne, pozostając pod właścicielskim, finansowym lub organizacyjnym wpływem

33 Dz. Urz. UE L 175 z 27.06.2013, s. 1-8.

34 A. Piskorz-Ryń, Ponowne wykorzystywanie informacji sektora publicznego. Zagadnienia administracyjnoprawne, Warszawa 2018, s. 148-149. 
organów sektora publicznego. Równocześnie na przedsiębiorstwa publiczne nie nałożono obowiązku zezwalania na ponowne wykorzystywanie ich dokumentów, wyłączając wobec nich tryb wnioskowy. $\mathrm{Z}$ tego względu, uwzględniając taką fakultatywność stosowania zasad ponownego wykorzystywania, w projekcie u.o.d.p.w. rozszerza się krąg podmiotów zobowiązanych m.in. o podmioty wykonujące jeden z rodzajów działalności sektorowej, o której mowa w ustawie z dnia 11 września 2019 r. - Prawo zamówień publicznych.

Dalsze merytoryczne zmiany w dyrektywie 2019/1024 dotyczą zwiększania podaży danych publicznych. Obejmują one rozszerzenie zakresu przedmiotowego ponownego wykorzystywania o kategorię danych dynamicznych, zbiorów danych o wysokiej wartości oraz danych badawczych. Pierwsza z nich obejmuje dokumenty $\mathrm{w}$ formie cyfrowej podlegające częstym aktualizacjom, które powinny być w miarę możliwości udostępniane natychmiast po ich zgromadzeniu za pośrednictwem odpowiednich interfejsów API ${ }^{35}$, z opcją zbiorczego pobrania ${ }^{36}$. Określono także nową kategorię zbiorów danych o wysokiej wartości, których ponowne wykorzystywanie wiąże się z istotnymi korzyściami dla społeczeństwa, środowiska i gospodarki. W załączniku do dyrektywy 2019/1024 zawarto wykaz tematycznych kategorii takich zbiorów, obejmując nimi dane geoprzestrzenne, dane dotyczące obserwacji Ziemi i środowiska, dane meteorologiczne, statystyczne, dane dotyczące przedsiębiorstw i ich własności oraz dane dotyczące mobilności. Zbiory danych wysokiej wartości powinny być udostępniane bezpłatnie, $w$ formacie do odczytu maszynowego, również za pośrednictwem interfejsów API i z opcją zbiorczego pobrania ${ }^{37}$. Ponadto na państwa europejskie nałożono nowy obowiązek przyjęcia polityki otwartego dostępu do danych badawczych, z wyłączeniem publikacji naukowych. Mają być one bezpłatnie udostępniane w zakresie, w jakim są finansowane ze środków publicznych i są publicznie dostępne ${ }^{38}$. Powyższe zasady ponownego wykorzystywania tych trzech szczególnych kategorii danych uwzględniono bez modyfikacji w projekcie u.o.d.p.w. ${ }^{39}$.

Kolejne istotne zmiany obejmują pobieranie opłat za ponowne wykorzystywanie informacji publicznej. Prawodawca unijny w miejsce dotychczasowej ograniczonej

35 Zgodnie z motywem 32 dyrektywy 2019/1024, API jest zestawem funkcji, procedur, definicji i protokołów do komunikacji maszyna-maszyna oraz płynnej wymiany danych. W świetle art. 2 pkt $9 \mathrm{w}$ zw. $\mathrm{z}$ art. 10 ust. 2 projektu u.o.d.p.w. API to interfejs programistyczny aplikacji stanowiący zbiór technicznych funkcji umożliwiających połączenie i wzajemną wymianę danych lub metadanych pomiędzy programami komputerowymi lub systemami teleinformatycznymi.

36 Zob. art. 5 ust. 5 i 6 dyrektywy 2019/1024.

37 Zob. art. 14 ust. 1-5 i art. 5 ust. 8 dyrektywy 2019/1024.

38 Zob. art. 10 dyrektywy 2019/1024 w zw. z art. 6 ust. 6 dyrektywy 2019/1024.

39 Zob. art. 22-26 projektu u.o.d.p.w. 
odpłatności ponownego wykorzystywania w dyrektywie 2019/1024 wprowadził zasadę bezpłatności, równocześnie dopuszczając możliwość odzyskiwania kosztów krańcowych poniesionych $\mathrm{w}$ związku z reprodukowaniem, udostępnianiem, rozpowszechnianiem dokumentów, a także anonimizacją danych osobowych oraz środkami zastosowanymi w celu ochrony poufnych informacji handlowych. Od tej zasady przewidziano jednak dalsze wyjątki dotyczące organów sektora publicznego, które muszą uzyskiwać dochody w celu pokrycia znacznej części kosztów związanych z wykonywaniem swoich zadań publicznych, a także bibliotek, muzeów, archiwów i przedsiębiorstw publicznych ${ }^{40}$. Podmioty te mogą uwzględnić szerszy katalog kosztów, m.in. rozsądny zwrot z inwestycji. Polski ustawodawca już w przepisach u.p.w.i.s.p. jako zasadę wskazał bezpłatność ponownego wykorzystywania, umożliwiającą jedynie fakultatywne nałożenie opłaty, ograniczone do przypadku, gdy przygotowanie lub przekazanie informacji w sposób lub w formie wskazanych we wniosku wymaga poniesienia dodatkowych kosztów. Łączna ich wysokość nie może jednak przekroczyć sumy kosztów poniesionych bezpośrednio w celu takiego przygotowania lub przekazania informacji ${ }^{41}$. Od tej zasady przewidziano wyłącznie dwa wyjątki, znacznie węższe niż w prawie unijnym. Pierwszy z nich obejmuje muzea państwowe i samorządowe, które mogą nałożyć wyższe opłaty, gdy ponowne wykorzystywanie informacji dotyczyć będzie innych celów niż niekomercyjne o charakterze badawczym, naukowym lub edukacyjnym, a drugi wyjątek dotyczy odrębnego trybu stałego dostępu online, umożliwiającego opłatę uwzględniającą koszty wynikające z dostosowania systemu teleinformatycznego, warunków technicznych i organizacyjnych do realizacji wniosk $\mathrm{u}^{42}$. W projekcie u.o.d.p.w. zasadniczo zachowano już obowiązujące zasady pobierania opłat, umożliwiając jedynie ustalenie opłaty uwzględniającej koszty anonimizacji danych osobowych i ochrony tajemnicy przedsiębiorstwa ${ }^{43}$. Wyłączono przy tym szczególne zasady pobierania opłat w przypadku dostępu online w zakresie danych dynamicznych i danych o wysokiej wartości, pomimo iż prawodawca unijny przewiduje bezpłatność ponownego wykorzystywania jedynie tej drugiej szczególnej kategorii danych. Polski ustawodawca konsekwentnie przyjmuje więc stanowisko bardziej liberalne od prawodawcy unijnego, ograniczając przesłanki pobierania opłat i nie uwzględniając możliwości przewidzianych w dyrektywach. Koszty funkcjonowania i rozwoju zasobów informacyjnych administracji nadal więc będą finansowane wyłącznie ze środków publicznych, bez partycypacji sektora prywatnego korzystającego z tych zasobów w celach

40 Zob. art. 6 Dyrektywy 2019/1024.

41 Zob. art. 16 i 17 u.p.w.i.s.p.

42 Zob. art. 18 i 19 u.p.w.i.s.p.

43 Zob. art. 18 ust. 3 projektu u.o.d.p.w. 
komercyjnych ${ }^{44}$. Z drugiej strony, zniwelowana zostanie możliwość ograniczania ponownego wykorzystywania przez ustalanie wysokich opłat.

W dyrektywie 2019/1024 przyjęto też nowe rozwiązania dotyczące ograniczeń ponownego wykorzystywania. Przewidziano nowe zasady przeciwdziałania nie tylko umowom o wyłączność, ale również uzgodnieniom prawnym lub praktycznym, które mają na celu ograniczenie dostępności dokumentów do ponownego wykorzystywania, a tym samym konkurencji na rynku danych publicznych. W tym zakresie projekt u.o.d.p.w. powiela dotychczasowe przepisy wyłączające możliwość zawarcia umowy na wyłączność, dopuszczonej wyjątkowo, gdy prawo wyłączne jest konieczne do świadczenia usług $w$ interesie publicznym ${ }^{45}$. Projektodawca zdaje się zatem nie dostrzegać zagrożeń wynikających z różnorodnych uzgodnień dotyczących praw wyłącznych, które chociaż tworzą bariery dostępności, to wprost nie przyznają prawa wyłącznego lub nie przybierają określonej formy prawnej. $\mathrm{W}$ projekcie u.o.d.p.w. nie objęto generalnym zakazem innych pozaumownych uzgodnień między organami sektora publicznego lub przedsiębiorstwami publicznymi będącymi w posiadaniu informacji publicznych a stronami trzecimi ${ }^{46}$, co byłoby zasadne w świetle implementowanej dyrektywy. Dalsze ograniczenia mogą wynikać z możliwości ustalania warunków ponownego wykorzystywania. Prawo unijne ogólnie wskazuje na zasadę bezwarunkowości, z możliwością ustalenia warunków obiektywnych, proporcjonalnych, niedyskryminacyjnych i uzasadnionych celem interesu publicznego ${ }^{47}$. Uregulowanie konkretnych warunków ponownego wykorzystywania pozostawiono więc ustawodawcy krajowemu. W przepisach u.p.w.i.s.p. określenie warunków przybiera charakter obligatoryjny tylko w przypadku, gdy podmiot zobowiązany przekazuje do ponownego wykorzystywania informacje mające cechy utworu lub przedmiotu praw pokrewnych lub stanowiące bazę danych, ze względu na konieczność ochrony praw własności intelektualnej podmiotów trzecich, w szczególności autorskich praw osobistych twórców. Dodatkowo przewidziano warunki fakultatywne dotyczące obowiązku poinformowania o źródle, czasie wytworzenia i pozyskania informacji od podmiotu zobowiązanego, o przetworzeniu informacji ponownie wykorzystywanej, a także warunki dotyczące zakresu odpowiedzialności podmiotu zobowiązanego za udostępniane lub przekazywane informacje oraz informacji sektora publicznego zawierającej dane

44 G. Sibiga, Opinia prawna o projekcie ustawy o zmianie ustawy o dostępie do informacji publicznej oraz niektórych innych ustaw (druk 4434), http://orka.sejm.gov.pl.

45 Por. art. 9 ust. 2 u.p.w.i.s.p. oraz art. 9 ust. 2 projektu u.o.d.p.w.

46 Zob. art. 12 ust. 1 dyrektywy 2019/1024.

47 Zob. 8 ust. 1 Dyrektywy 2019/1024. 
osobowe $^{48}$. Projekt u.o.d.p.w. zasadniczo utrzymuje dotychczasowy katalog dopuszczalnych warunków, przy czym istotna zmiana dotyczy nadania obligatoryjnego charakteru warunkom dla informacji stanowiących dane osobowe ${ }^{49}$. Równocześnie, w ślad za przepisami unijnymi, rozszerzeniu ulegnie katalog ograniczeń ponownego wykorzystywania. Obecnie obejmuje on ochronę informacji niejawnych $\mathrm{i}$ innych tajemnic ustawowo chronionych, ochronę tajemnicy przedsiębiorstwa lub prywatności osoby fizycznej, ochronę szczególnych zasobów publicznych oraz informacji wytwarzanych poza zakresem zadań publicznych, jak również ochronę depozytów, praw własności intelektualnej osób trzecich i zasobów muzeów, bibliotek i archiwów. Nowe ograniczenia obejmą ochronę infrastruktury krytycznej oraz informacje stanowiące program komputerowy.

Projekt u.o.d.p.w. zasadniczo wpisuje się w powyższe kierunki zmian określone przez prawodawcę unijnego. Wskazać jednak należy na niektóre mankamenty projektowanych przepisów, jak powielany w art. 6 ust. 4 pkt 3 projektu u.o.d.p.w. błąd sformułowania ograniczenia ponownego wykorzystywania z odwołaniem się do przepisów ustawy z dnia 30 czerwca 2000 r. - Prawo własności przemysłowej. Zgodnie z motywem 54 dyrektywy 2019/1024 nie ma ona zastosowania do dokumentów objętych prawem własności przemysłowej, takich jak patenty, zarejestrowane wzory i zarejestrowane znaki towarowe. W tej materii właściwa implementacja prawa unijnego powinna zmierzać do przedmiotowego wyłączenia informacji objętych prawem własności przemysłowej, a nie tworzenia ograniczenia, które nie chroni tych praw należących do podmiotów zobowiązanych. W projekcie u.o.d.p.w. zawarto również istotne zmiany instytucjonalne. Projektodawca przewiduje utworzenie portalu otwartych danych, który zastąpić ma obecny CRIP. Towarzyszyć temu będzie opracowanie przez ministra właściwego do spraw informatyzacji programu otwartych danych, mającego na celu zwiększenie ilości oraz poprawę jakości informacji udostępnianych na portalu otwartych danych. W części urzędów obowiązkowo zostanie powołany pełnomocnik do spraw otwartości danych, który realizować będzie założenia tego programu. Zwrócić uwagę należy jednak na art. 29 ust. 2 projektu u.o.d.p.w., który przewiduje szeroki katalog podmiotów zobowiązanych do udostępniania posiadanych informacji na portalu otwartych danych. Proponowany katalog obejmuje wszystkie podmioty zobowiązane, z wyłączeniem przedsiębiorstw publicznych. Na portalu mają być udostępniane tylko takie informacje sektora publicznego, które posiadają szczególne znaczenie dla rozwoju innowacyjności w państwie i rozwoju społeczeństwa informacyjnego, a ponadto które ze względu na sposób przechowywania i udostępniania pozwalają na ich

48

Zob. art. 14 ust. 1 u.p.w.i.s.p.

49 Zob. art. 14 ust. 4 projektu u.o.d.p.w. 
ponowne wykorzystywanie w rozumieniu projektu ustawy w sposób użyteczny i efektywny. Projektodawca zakłada więc, że wszystkie informacje sektora publicznego,będące $\mathrm{w}$ posiadaniu podmiotów zobowiązanych $\mathrm{z}$ wyłączeniem przedsiębiorstw publicznych powinny podlegać ocenie według tak określonego szczególnego charakteru. Nie precyzuje jednak kryteriów zakwalifikowania informacji jako posiadających znaczenie dla rozwoju innowacyjności lub społeczeństwa informacyjnego, co może umożliwić uznaniową ocenę zasobów i ich wykluczenie z obowiązku udostępnienia. $\mathrm{W}$ dotychczasowym art. 9a ust. 2 u.d.i.p. do przekazania informacji do CRIP, zastępowanego portalem otwartych danych, zobowiązano jedynie część podmiotów zobowiązanych, m.in. organy administracji rządowej, ZUS, KRUS i NFZ. Ewentualne rozszerzenie tego katalogu podmiotów powinno zostać poprzedzone rzetelną analizą, której w świetle Oceny Skutków Regulacji projektu u.o.d.p.w. zabrakło, wskazującą, które podmioty posiadają informacje o szczególnym wymaganym walorze. Zauważyć również należy, że ponowne wykorzystywanie informacji ma charakter użytkowy, a jego celem jest wytworzenie nowych produktów, usług lub dóbr o wartości dodanej. Nie wszystkie informacje sektora publicznego mogą zaś stanowić materiał adekwatny do tego celu.

Zmianom ulec mają również aspekty proceduralne. W świetle art. 42 ust. 1 projektu u.o.d.p.w. organem odwoławczym od decyzji o odmowie wyrażenia zgody na ponowne wykorzystywanie informacji sektora publicznego oraz od decyzji o warunkach ponownego wykorzystywania lub o wysokości opłat za ponowne wykorzystywanie jest minister właściwy do spraw informatyzacji. W uzasadnieniu projektu wskazano, że minister ten ,jako organ właściwy w sprawach z zakresu ponownego wykorzystywania informacji sektora publicznego (organ regulujący dostęp do informacji sektora publicznego w Polsce), rozpatrując odwołania od decyzji wydawanych przez podmioty zobowiązane, pełnić będzie w ten sposób (jako organ II instancji) rolę bezstronnego organu odwoławczego posiadającego odpowiednią wiedzę specjalistyczną". Postulat utworzenia jednego organu odwoławczego właściwego w sprawach dostępu do informacji publicznej był obecny w doktrynie, jednakże obejmował utworzenie niezależnego osobowo, organizacyjnie i kompetencyjnie, centralnego, kadencyjnego i monokratycznego organu administracyjnego. Rekomendowano przy tym połączenie funkcji niezależnego organu ds. dostępu do informacji publicznej oraz Generalnego Inspektora Ochrony Danych Osobowych ${ }^{50}$. Przede wszystkim minister właściwy do spraw informatyzacji nie spełnia kryteriów niezależności, a ponadto nie reguluje dostępu do informacji sektora publicznego, ze względu na obowiązujące w Polsce zasady procesu legislacyjnego. Proponowana zmiana organu odwoławczego jest przy tym niespójna

50 Zob. A. Młynarska-Sobaczewska, P. Fajgielski, A. Piskorz-Ryń, G. Sibiga, op. cit., s. 18-21. 
z pozostającymi bez zmian przepisami u.d.i.p., podczas gdy to system dostępu ma być oparciem dla ponownego wykorzystywania informacji publicznej. Dotychczas, analogicznie jak w przypadku dostępu do informacji publicznej, do decyzji w sprawach ponownego wykorzystywania i ich kwestionowania na drodze odwoławczej stosuje się ogólne zasady z ustawy z dnia 14 czerwca 1960 r. - Kodeks postępowania administracyjnego. Negatywnie należy zatem ocenić ten kierunek zmian zmierzający do centralizacji rozpatrywania odwołań. Zasadnie krytykowano taką koncepcję, wskazując, że taka centralizacja wydłuży czas załatwiania spraw, wpłynie na jakość rozpatrzenia odwołań, które wnoszone w skali kraju obciążą jeden organ, a ponadto utrudni dostęp do sądu, ponieważ jedynym miejscowo właściwym do rozpoznania skarg na decyzje ministra z siedzibą w Warszawie, będzie tamtejszy wojewódzki sąd administracyjny ${ }^{51}$.

Kolejna propozycja zmian zawarta została w art. 49 pkt 4 projektu u.o.d.p.w. Zakłada ona nowelizację przepisów u.d.i.p. w ten sposób, że podmiot obowiązany, udostępniając informację publiczną na wniosek, może określić warunki ponownego wykorzystywania informacji, a brak ich określenia oznaczać będzie zgodę na ponowne wykorzystywanie informacji bez spełnienia przez wnioskodawcę jakichkolwiek warunków. Projektowana zmiana skutkować będzie koniecznością zastosowania regulacji prawnych ponownego wykorzystywania w toku każdorazowego udostępniania informacji publicznej na wniosek $w$ trybie i na zasadach ustawy o dostępie do informacji publicznej. Taki nowy obowiązek stanowi nieuzasadniony wyjątek od wyodrębnienia tych dwóch niezależnych uprawnień informacyjnych, jak i wyjątek od zasady, że to wnioskodawca, jako gospodarz inicjowanego wnioskiem postępowania, powinien dać wyraz intencjom wniosku i sformułować przedmiot żądania, wytyczający zakres działań podmiotu zobowiązanego. Biorąc pod uwagę odrębne uregulowanie i zdefiniowanie ponownego wykorzystywania względem dostępu do informacji na gruncie dyrektyw unijnych i w polskim porządku prawnym, prawo dostępu do informacji i dokumentów automatycznie nie przekłada się na uprawnienie do ich ponownego wykorzystywania. Skoro ustawodawca, implementując przepisy unijne, wyraźnie rozróżnił polityczne prawo dostępu do dokumentów od gospodarczego prawa ponownego ich wykorzystywania, aktualnie nie powinien mieszać tych dwóch uprawnień na etapie ich realizacji przez wnioskodawców. Może to także wywołać wiele problemów praktycznych. Dostęp do informacji publicznej jest odformalizowany, a wniosek o udostępnienie informacji publicznej nie musi spełniać szczególnych wymogów. Szczególna sytuacja dotyczy informacji publicznych mających cechy utworu lub przedmiotu praw pokrewnych lub stanowiących bazę danych. W takim przypadku

51 Zob. P. Szustakiewicz, Przyszłość regulacji o dostępie do informacji publicznej..., s. 733. 
warunki ponownego wykorzystywania są obligatoryjne, jak też powinny uwzględniać zasady licencjonowania utworów, w tym określać pola eksploatacji. Tymczasem we wniosku o udostępnienie informacji publicznej wnioskodawca nie ma obowiązku wskazywania zarówno propozycji warunków, jak i celu ponownego wykorzystywania, w tym dóbr, produktów i usług, które zamierza wytworzyć. Może to uniemożliwić ustalenie adekwatnych do celu warunków na etapie realizacji wniosku o dostęp do informacji publicznej.

Podsumowując, rozszerzanie jawności działań administracji publicznej oraz poprawy stanu otwartości danych publicznych jest stałym celem deklarowanym przez ustawodawcę. Kierunki zmian wpisują się w budowę administracji opartej na otwartych danych publicznych, która nie tylko zapewni szeroki dostęp do informacji publicznej, ale również wytworzy i zgromadzi dane w sposób umożliwiający ich dalsze gospodarcze wykorzystywanie przez sektor prywatny. Wskazywane problemy i wątpliwości dotyczą fundamentalnych aspektów dostępu do informacji publicznej i istotnych zagadnień związanych z tworzeniem ram prawnych dla otwartych danych administracji. Zasadne wydaje się stwierdzenie, że zarówno rozwiązanie już obecnych problemów $w$ realizacji praw informacyjnych, jak i wdrożenie projektowanych zmian będą znacznym wyzwaniem dla administracji. Dlatego niezależnie od już wskazanych postulatów natury legislacyjnej należy także zaproponować pewne rozwiązania praktyczne. Materia dostępu i ponownego wykorzystywania informacji publicznej już jest dość złożona i skomplikowana, a zaprezentowane kierunki zmian i nowe obowiązki dotyczące obsługi portalu otwartych danych czy też realizacji programu otwierania danych skutkować będą dalszym rozszerzaniem zadań administracji w zakresie udostępniania informacji. Równocześnie załatwianie konkretnych spraw informacyjnych jest coraz bardziej wymagające, zwłaszcza ze względu na konieczność interpretacji i stosowania niejasnych i wieloznacznych pojęć o podstawowym znaczeniu. Wymaga to profesjonalnego przygotowania organizacyjnego i personalnego administracji. Należy postulować konieczność wyodrębnienia wewnętrznych komórek organizacyjnych w obrębie organów pomocniczych obsługujących poszczególne organy administracji wszystkich szczebli. Takie wyspecjalizowane komórki powinny w zakresie regulaminowych zadań posiadać koordynację procesu udostępniania i przekazywania informacji publicznej, w tym do ponownego jej wykorzystywania, jak również podlegać bezpośrednio kierownikom jednostek i być organizacyjnie związane z wewnętrzną obsługą prawną organu zapewniającą wykonywanie zastępstwa procesowego przed sądem. Pracowników takich wyodrębnionych komórek należy skierować na niezbędne szkolenia, aby następnie przy ich pomocy zapewnić szkolenia wewnętrzne. Nie mogą oni realizować spraw dostępu do informacji jedynie przy okazji, dlatego powinni zostać wyłączeni z realizacji innych zadań meryto- 
rycznych. Zapewni to przejrzyste zasady odpowiedzialności za realizowane sprawy dostępowe, a ponadto uczyni te sprawy głównym przedmiotem ich pracy i zainteresowania. Profesjonalna i świadoma obsługa procesu udostępniania i przekazywania informacji publicznej jest nie tylko warunkiem wdrażania dalszych zmian mających na celu poszerzanie jawności życia publicznego, ale także jest koniecznością dla przyszłości autorytetu administracji w zmieniającej się rzeczywistości.

\section{Bibliografia}

\section{Literatura}

Dubisz S. (red.), Wielki Stownik Języka Polskiego PWN, t. 2, H-N, Warszawa 2018.

Fajgielski P., Informacja w administracji publicznej. Prawne aspekty gromadzenia, udostęniania i ochrony, Wrocław 2007.

Młynarska-Sobaczewska A., Fajgielski P., Piskorz-Ryń A., Sibiga G., Ekspertyza prawna „Rozwiązania mogące stanowić podstawę do zmian przepisów regulujących zasady dostępu do informacji publicznej i jej ponownego wykorzystywania", https://mc.bip.gov.pl/fobjects/ download/96100/rozwiazania-mogace-stanowic-podstawe-do-zmian-przepisowregulujacych-zasady-pdf.html (dostęp: 30.10.2020).

Piskorz-Ryń A, Ponowne wykorzystywanie informacji sektora publicznego. Zagadnienia administracyjnoprawne, Warszawa 2018.

Sibiga G., Opinia prawna o projekcie ustawy o zmianie ustawy o dostępie do informacji publicznej oraz niektórych innych ustaw (druk 4434), http://orka.sejm.gov.pl (dostęp: 30.10.2020).

Sokolewicz W., Wojtyczek K, [w:] L. Garlicki, M. Zubik (red.), Konstytucja Rzeczypospolitej Polskiej. Komentarz, t. 2, Warszawa 2016.

Szustakiewicz P., Definicja informacji publicznej w orzecznictwie Naczelnego Sądu Administracyjnego, „Przegląd Prawa Publicznego" 2016, 10.

Szustakiewicz P., Problemy dostępu do informacji publicznej na tle orzecznictwa sądów administracyjnych, "Samorząd Terytorialny” 2015, 4.

Szustakiewicz P., Przyszłość regulacji o dostępie do informacji publicznej (uwagi na tle ekspertyzy prawnej "Rozwiązania mogące stanowić podstawę do zmian przepisów regulujących zasady dostępu do informacji publicznej i jej ponownego wykorzystywania" sporządzonej przez Instytut Nauk Prawnych PAN), [w:] J. Sługocki (red.), Dziesięć lat polskich doświadczeń w Unii Europejskiej. Problemy prawnoadministracyjne, t. 2, Wrocław 2014.

Tomaszewska K., Dostęp do informacji publicznej w świetle obowiq̨zujących i przysztych regulacji, Warszawa 2019.

Ulasiewicz M.I., Administracyjnoprawne aspekty jawności działań administracji publicznej, Łódź 2017.

\section{Orzecznictwo}

Wyrok TK z 9.11.1999 r., K 28/98, OTK 1999/7/156.

Wyrok TK z 17.12.2003 r., SK 15/02, OTK-A 2003/9/103. 
Wyrok NSA z 5.03.2013 r., I OSK 3097/12, CBOSA. Wyrok NSA z 7.10.2015 r., I OSK 1883/14, CBOSA. Wyrok NSA z 2.12.2015 r., I OSK 2337/15, CBOSA. Wyrok NSA z 20.09.2016 r., I OSK 2649/15, CBOSA. Wyrok NSA z 21.10.2016 r., I OSK 446/15, CBOSA. Wyrok NSA z 23.11.2018 r., I OSK 2951/16, CBOSA. Wyrok NSA z 23.01.2019 r., I OSK 431/17, CBOSA. Wyrok NSA z 12.04.2019 r., I OSK 1648/17, CBOSA. Wyrok WSA w Warszawie z 9.07.2014 r., VIII SA/Wa 529/14, CBOSA. Wyrok WSA w Opolu z 22.08.2018 r., II SA/Op 334/18, CBOSA. 